\title{
Creating positive friction in the Anthropo(s)cenes
}

Samuel Randalls

Department of Geography, University College London, Gower Street, London, WC1E 6BT, UK

s.randalls@ucl.ac.uk,+44 02076797575

Abstract: In responding to Castree's argument that geographers can and should encourage the production of a wider set of knowledges within the Anthropo(s)cene communities, I suggest that such a process needs to: first, recognize the multiplicity of the Anthropo(s)cene scientifically, politically and ethically; and second, to actively participate in the politics of the Anthropo(s)cene by providing positive friction. This concurs with much of Castree's paper and emphasizes the necessity of recognizing the intertwined science-politics of the Anthropo(s)cenes, the importance of asking awkward historical questions and the value of foregrounding debates about the future lives we wish to lead and planet we wish to inhabit.

Keywords: Anthropocene; ontological politics; multiple; resilience; natural climate 


\section{Creating positive friction in the Anthropo(s)cenes}

Noel Castree sets out the possibilities and pitfalls of the increasingly-significant idea of the Anthropocene for geographical research. Castree hopes that geographers will be positioned at the heart of the emerging web of institutions, research projects and networks that constitute this 'Anthropo(s)cene', while at the same time critically re-shaping this scene to ensure that it promotes contributions from a wider array of humanities and social science scholars. While the geological debates are ongoing, the Anthropocene is taking on a political life through the reshaping and reconstituting of funding, discourses, practices and visions of the future. The focus on the Anthropocene also represents the most recent gambit towards integrationism - another area especially espied by geographers - following other approaches such as resilience, socio-ecological systems, multi-scalar relationships, integrated assessments, political ecology or various iterations of applied physical geography. In this commentary, I wish to take up two primary inter-related points that follow from Castree's important contribution. First, that the Anthropo(s)cene is thoroughly multiple and 'the Anthropocene' should not be taken to inspire a singular scientific, political or ethical view. Second, with this multiplicity we can then identify the sites of contestation and debate (or 'friction' to borrow a term in part from Mol, 2002) and encourage a critical and broader range of ideas within the Anthropo(s)cene communities.

If the integrationism of the Anthropocene is not new as such (as the previous list demonstrates), the crucial question then is, what does 'the Anthropocenic gaze' (Wahlberg, 2014) inspire? What are the politics of and for living in, through, with and constituting the Anthropocene? What is different about this concept? Castree draws attention to these questions by exploring critical literatures on global change science. This seems to me to be an eminently important strategy. We should not accept that all global change science is equal; there is a politics of science (and beyond) at stake too. Some scientists recognize this in the dating of the start of the Anthropocene, on which 
there is a lively debate. This is not just a purely scientific exercise, but is equally about what the concept of the Anthropocene might do politically. Lewis and Maslin (2015) argue that the start date of the Anthropocene has an important effect on the stories we will tell about nature and society the extent to which and when humans are to be blamed for (un)knowingly influencing the planet; the emphasis given to unequal global trade patterns or industrialisation; whether the focus is on humankind in general or the story of the development of the bomb by an elite group of researchers with far-reaching consequences for humanity; and so on. The Anthropocene's start date, then, is considered to inspire different kinds of ethical and political concerns. It is why Hamilton and Grinevald (2015: 67) are so scathing of the historical tracing of precursors of the Anthropocene as they might "gradualize the new epoch so that it is no longer a rupture due principally to the burning of fossil fuels." This emphasises the more-than-scientific significance and motivations of the Anthropo(s)cene literature.

At this point, one could simply discount or dismiss the Anthropocene as the latest catchphrase (whatever one thinks of the motivations). But I think this would be a premature reaction, not least because the Anthropocene idea is being and will be deployed in different ways by different communities. There will be uneasy coexistence and friction between multiple, different Anthropo(s)cenes. I take Castree's call to be one that tries to enact these in ways that are supportive of critical geographical scholarship. This requires some bravery in conversation and publication as Castree suggests, but it also means acknowledging that there is no singular Anthropocene community with which to interface with or critique, or from which a 'new' Anthropocenic ethics or politics can be singularly constructed. It is worth illustrating this point in further detail.

To some extent the idea of the Anthropocene admits the kind of arguments that geographers have long made about the anthropogenic shaping of the planet's ecologies. For example, Caseldine (2014) argues that the Anthropocene has forced climate management on us, because by its very nature there is no longer such a thing as natural climate. In ecology, the 
Anthropocene appears to remove the grounds of essentialist dualisms like domestic-wild, natureculture and native-exotic. The IUCN's definition of a natural baseline is potentially troubled as are the distinctions made in arguments about in situ versus ex situ biodiversity conservation (Braverman, 2014). But, at another level, as Castree notes, there is a retreat to quasi-scientific modelling of human processes which are to be 'managed' in this new era. Ironically the kinds of science and social science that shape some (many?) of the Anthropo(s)cene communities seem to resort again to forms of environmental reductionism or a restrictive quantitative social science. Likewise politically, as Castree points out, it is at best not clear that embracing the Anthropocene inspires less attention to, for example, technological fixes such as geoengineering which if anything gain legitimacy from the perceived death of naturalness. 'Since humans are shaping the global environment anyway', geoengineering enthusiasts might reason, 'perhaps it is best to use technology to directly command that process.'

In sum, the Anthropo(s)cene has no singular scientific, environmentalist or political logic. We therefore cannot simply posit a contribution for humanities and social science that emerges because of the Anthropocene as though politics and ethics simply flow from science. There are frictions, tensions, and debates between and within different Anthropo(s)cene communities, and this is where much of the positive critical energies of geographers can be most effective. Rather than asking what kinds of arts the Anthropocene inspires, as a way to 'get in' on the debate, perhaps we can better ask what kinds of Anthropo(s)cenes are being and can be enacted through different scientific and artistic techniques. Instead of asking what the political implications of the Anthropocene are, we can ask where the frictions are, what are the productive possibilities and interventions opened up through specific articulations of the Anthropocene and with what kinds of consequences.

Accepting that the Anthropo(s)cene is both ontologically and epistemologically multiple, what might a critical politics that interferes and engages with the Anthropo(s)cene look like? One ready-made link is through ideas of resilience (for example Ogden et al. 2013). The image of the 
transformed earth in the Anthropocene aligns quite readily with classic concepts of socio-ecological systems and resilience. These ideas, however, have deeper roots that we might wish to carefully consider. As Walker and Cooper (2011) argue, there are striking parallels between Holling's ecological arguments and Hayekian (and also Schumpeterian) economics. For Walker and Cooper (2011) resilience emerged as a critique of destructive resource management, but its epistemologically intuitive fit with neoliberal philosophies has morphed it to a position of collusion with contemporary political-economic practices. Likewise, Hamilton and Grinevald (2015) suggest that the idea of the Anthropocene ushers in a new critique of contemporary industrial society, an argument that Castree directly gestures towards in his reference to Naomi Klein's (2014) comment on 'secret fifth columnist' climate researchers. It is a point, however, that as Castree notes needs to be turned inwards on the global science communities too.

At the very least, even if the Anthropo(s)cene begins with an element of societal critique, it is not clear that this will be maintained given the way in which the idea is proliferating among powerful groups of researchers and institutions. Will a diversity of voices be heard or will they be reduced to an Anglophone, global change science that is dominated by a few core institutions, frameworks and disciplines? Part of Ogden et al.'s (2013) argument is that Anthropocene researchers need to understand how global assemblages intertwine with 'the local' and the inequalities that emerge through these multi-scalar connections. As Hulme (2010: 563) suggests "a geography of global environmental change demands, rather paradoxically, that attention turns away from the globalising instincts that so easily erase distinction and which seek consensus." The latter point is especially pertinent: consensus in/on the Anthropocene is not necessarily desirable. Other forms of consensual environmental politics have not always been particularly progressive or meaningful (Swyngedouw, 2010) and some scientists have been more-than-willing to cash in on environmental issues. It is at least a question worth asking whether the Anthropo(s)cenes perpetuate a cosy political co-existence of resilience and neoliberalism that primarily re-enforces conservative ideals or whether they (also) have the potential to open up new possibilities (Simon 
and Randalls, forthcoming). These are the kinds of uncomfortable frictions (ontological, epistemological, political) that need to be exposed and debated in the Anthropo(s)cene.

I take Castree's provocation for critical scholarship in the Anthropo(s)cene as an invitation to find ways to enable different, potentially more marginal voices to be heard and represented, a role that he sees geographers as being particularly suited to play. For Castree, this multiplicity is all to the good, with "plural answers rather than 'clever solutions'." The Anthropocene provides an entrypoint with both global change scientists and practitioners to start fresh conversations about our future planet and the lives we wish to lead. If geographers join in, Castree reasons, we might shape the Anthropo(s)cene in progressive, interesting and productive ways. It is a much better proposition than standing on the sidelines. But crucially we must remember that there is no singular Anthropo(s)cene science, ethics or politics. We need to ask what disparate appeals to the Anthropocene do and what kinds of futures they enable or disable. We need to recognize that science and politics are thoroughly entwined in the Anthropo(s)cene. This means critically evaluating rather than blithely accepting core concepts like planetary boundaries and safe operating spaces. In so doing, we can open up new insights for the Anthropo(s)cene rather than simply following the global change science communities. We can help create positive frictions.

\section{References}

Braverman I (2014) Conservation without nature: the trouble with in situ versus ex situ conservation. Geoforum 51: 47-57.

Caseldine C (2014) So what sort of climate do we want? Thoughts on how to decide what is 'natural' climate. The Geographical Journal. Epub ahead of print October 2014. DOI: 10.1111/geoj.12131. 
Hamilton C and Grinevald J (2015) Was the Anthropocene anticipated? The Anthropocene Review 2(1): 59-72.

Hulme M (2010) Problems with making and governing global kinds of knowledge. Global Environmental Change 20(4): 558-564.

Klein N (2014) This changes everything: Capitalism vs the climate. New York: Simon and Schuster. Lewis SL and Maslin MA (2015) Defining the Anthropocene. Nature 519(7542): 171-180.

Mol A (2002) The body multiple: Ontology in medical practice. Durham, NC: Duke University Press.

Ogden L, Heynen N, Oslender U, West P, Kassam K-A and Robbins P (2013) Global assemblages, resilience, and earth stewardship in the Anthropocene. Frontiers in Ecology and the Environment 11(7): 341-347.

Simon S and Randalls S (forthcoming) Geography, ontological politics and the resilient future. Dialogues in Human Geography

Swyngedouw E (2010) Apocalypse forever? Post-political populism and the spectre of climate change. Theory, Culture and Society 27(2-3): 213-232.

Wahlberg A (2014) Human activity between nature and society: The negotiation of infertility in China. In: Hastrup K (ed.), Anthropology and Nature. New York: Routledge, pp. 184-195. 
Walker J and Cooper M (2011) Genealogies of resilience: From systems ecology to the political economy of crisis adaptation. Security Dialogue 42(2): 143-160. 